\title{
Protein biomass quantification of unbroken individual foraminifers using nano-spectrophotometry
}

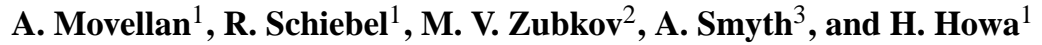 \\ ${ }^{1}$ LUNAM Université, Université d'Angers, Laboratoire des Bio-Indicateurs Actuels et Fossiles, CNRS UMR6112 \\ LPGN-BIAF, 2 Boulevard Lavoisier, 49045 Angers CEDEX 01, France \\ ${ }^{2}$ National Oceanography Centre, Southampton, University of Southampton, European Way, Southampton SO14 3ZH, UK \\ ${ }^{3}$ Department of Physics, University of Malta, Msida, MSD 2080, Malta
}

Correspondence to: A. Movellan (aurore.movellan@etud.univ-angers.fr)

Received: 9 May 2012 - Published in Biogeosciences Discuss.: 7 June 2012

Revised: 14 August 2012 - Accepted: 19 August 2012 - Published: 12 September 2012

\begin{abstract}
The ecological role of foraminifers has been largely unknown partly owing to difficulties in determining their individual biomass, although foraminifers are abundant in surface marine sediments. The present study provides a reliable and inexpensive method for the quantification of the protein content of hard-shelled foraminifers as a measure of biomass while preserving the tests for later analyses (e.g. morphometry, stable isotopes), using nanospectrophotometry. The protein biomass, is significantly correlated with size, and shell weight of Ammonia tepida $(n=$ 102, $p<0.00001, R^{2}=0.462$, and $n=181, p<0.00001$, $\left.R^{2}=0.855\right)$. Variability in the relation between test size and weight, and cell biomass may result from natural variability in horizontal and vertical microenvironments encompassing metabolic state, as well as variability in test morphometry and calcite mass (i.e. test weight). In turn, knowing the sizeand species-specific biomass of foraminifers adds valuable information on the trophic and ecologic conditions of modern and ancient marine environments, in particular on the reconstruction of the regional palaeoproductivity and flux of organic matter.
\end{abstract}

\section{Introduction}

Due to their abundance and the high fossilization potential, foraminifers are among the most utilized proxies in palaeoceanography and marine environmental reconstruction (Fischer and Wefer, 1999). The abundance of benthic foraminifers is attributed to their tolerance of a broad range of marine environmental conditions from mud-flats to the deepest parts of the world's oceans, constituting a significant part of the meiobenthos abundance and biomass (e.g. Moodley et al., 2000; Witte et al., 2003; Murray, 2006; Gooday et al., 2008). Food provides energy to heterotrophic organisms, including foraminifers, and organic carbon supply is considered the single most important factor limiting the growth of foraminifers in well-oxygenated normal marine environments (e.g. Lutze and Coulbourn, 1984; Jorissen et al., 1995). The export production and flux of particulate organic matter in the deep-water column and at the sea floor are known from empirical relations (e.g. Suess, 1980), and are better constrained since less variable in the deep sea than at shallow water depth (cf. Murray, 2001). Large ranges of primary production and organic carbon flux seem to be related to benthic foraminifer faunas, which are characterized by different species assemblages (Altenbach et al., 2003). While standing stocks seem to be controlled by the abundance of food (i.e. organic carbon flux), the distribution of foraminifers at the species level is much less well constrained (Altenbach et al., 1999; Murray, 2001). The relation of food supply and the distribution of foraminifers at the species level is anecdotal, in particular at shallow waters, and much better estimates of primary productivity and modern organic carbon flux are required to improve the reconstruction of past flux rates (Altenbach et al., 1988; Lutze and Altenbach, 1988; Murray, 2001). Consequently, the relation between food availability and the biomass of foraminifers needs to be calibrated at the species level and for a wide range of modern shallow- to deep-water environments to facilitate a much more accurate 
reconstruction of regional and basin-scale palaeoproductivity using transfer functions.

The ecological role of foraminifers in modern and past oceans has been largely unknown, partly owing to methodological difficulties in determining their individual biomass (Murray, 2006). No attempt was taken to measure individual foraminifer biomass since the work of Altenbach (1985, 1987). Using the method of Altenbach (1985), the foraminifer test needs to be disintegrated to measure the organic carbon content though, impeding further analyses of the test, the latter being important for further palaeoceanographic interpretation of the biomass data. As such, it is important to preserve the tests for further analysis during the procedure of biomass analysis.

We have developed and calibrated a new, non-destructive technique for protein biomass analysis of foraminifers, applying nano-spectrophotometry. The method is inexpensive, reliable, and easy to apply at any land-based and sea-going laboratory. Experiments were designed both to quantitatively analyse foraminifers for their protein biomass and to preserve the foraminifer test for morphometric analyses and calcite weight. The new method is quick and easy to apply in the laboratory and even on small research vessels, and the data are reproducible. In addition, we present $\sim 600$ new data on cytoplasm and test mass of the neritic benthic foraminifer species Ammonia tepida from the French Atlantic coast and laboratory cultures. The species has been chosen because it has been intensely studied (Morvan et al., 2006), and growth and reproduction rates are known (Bradshaw, 1957; Goldstein and Moodley, 1993). In turn, the solid shell and small aperture of Ammonia tepida impedes easy access of the analytical chemicals to the cytoplasm, and we present alternative methods (osmotic shock, ultrasonication, and $\mathrm{NaOH}$ treatment) to quantitatively measure the foraminifer cytoplasm. As such, Ammonia tepida constitutes a worst-case study, and the methods presented here could possibly be successfully applied to most of the common foraminifer species for quantitative biomass analyses. The final aim of this study is to provide a new technique and data to facilitate calibration of the modern foraminifer biomass for the application to paleoecological and palaeoceanographic reconstruction.

\section{Materials and methods}

A series of experiments was conducted with the aim to optimize a protocol of foraminifer cytoplasm measurement with a standard bicinchoninic method for protein quantification (Smith et al., 1985), in connection with analyses of the foraminifer test size and weight. The first experiments were designed to find a method alternative to crushing of the foraminifer shells to access the cytoplasm. Ammonia tepida are relatively thick-walled and have small apertures causing limited contact of analytical chemicals and cytoplasm. The easiest method to sidestep this problem is to crush the shell, but this would impede later analyses of the test morphology. Therefore, different methods were tested to break the cellular membrane for cytoplasm analyses, such as osmotic shock (with Milli-Q water and micro-filtered tap water), ultrasound treatment (for 2 and $5 \mathrm{~s}$ ), and $\mathrm{NaOH}$ treatment. All experiments were designed to compare protein content of unbroken individuals with the protein content of crushed individuals, the latter of which served as a control group (see tables for a global overview of the different experiments). After the experiments, the presence of biases (1) linked to the small amount of proteins measured, and biases due to (2) variation in the duration of incubation time of foraminifer sample solution (FSS) between the first and the last measurements was checked. The preservation of tests was continuously assessed in all experiments. A detailed protocol of the preparation of foraminifers with the different treatments is given below. Finally, the relation between the foraminifer protein content and test size was assessed, as well as a potential impact of cultivation time (laboratory conditions and feeding combined) on protein content.

The chemical reagent used for the analyses of foraminifer protein content is a mixture of copper solution (SigmaAldrich) and bicinchoninic acid (BCA, Sigma-Aldrich) solution (Smith et al., 1985; Zubkov et al., 1999; Mojtahid et al., 2011). The $\mathrm{Cu}^{2+}$ contained in the copper solution is reduced to $\mathrm{Cu}^{+}$by the proteins. The newly formed $\mathrm{Cu}^{+}$reacts with the BCA and a strong purple colour is produced. The intensity of the colour increases proportionally with protein concentration, and the absorbance of the 562-nm wavelength was measured with a nano-spectrophotometer (NanoDrop 2000, Thermo Scientific). Analysis with a NanoDrop 2000 requires only $2 \mu$ of solution, which allows several measurements of each standard and FSS (including BCA solution). Each standard and FSS was measured in triplicate.

Morphometric analyses of the foraminifer tests were carried out with an automated incident light microscope driven by analySIS ${ }^{\circledR}$ software (Bollmann et al., 2004; Clayton et al., 2009), installed at the University of Angers. A microbalance (Mettler Toledo XP2U) with a precision of $0.1 \mu \mathrm{g}$ was employed to weigh the dry and empty individual foraminifer tests. The microbalance was used in an air-conditioned room at constant temperature and humidity. Each test was acclimatized in the weighing room for at least $12 \mathrm{~h}$ before weighing.

The software R (v.12.2.1) was used for analysis of the data and calculation of the regressions. All comparisons of the protein distributions were carried out using variance analyses. All regressions presented are exponential functions following the allometric development of A. tepida.

\subsection{Sampling, cultivation, and preparation of the foraminifers}

Ammonia tepida were sampled from the mud flats of the Baie de l'Aiguillon, $10 \mathrm{~km}$ north of La Rochelle, French Atlantic coast, $46^{\circ} 15^{\prime} 17^{\prime \prime} \mathrm{N}, 1^{\circ} 8^{\prime} 27^{\prime \prime} \mathrm{W}$, on 13 May, 20 July, 
and 23 November 2010 (Table 1). The sampling site was chosen because of the high abundance of the benthic foraminifer species $A$. tepida. The samples were transferred ( $\sim 2 \mathrm{~h}$ drive $)$ to the laboratory at Angers University in a cool box, and washed through a $63-\mu \mathrm{m}$ sieve with $0.45-\mu \mathrm{m}$ micro-filtered seawater. Microfiltration of the water ensured that the bacteria were removed and contamination was avoided. In May, July, and November, first batches of 45, 60, and 104 specimens, respectively, were immediately picked after sampling, cleaned, and measured for their protein biomass (Table 1). The spare individuals were cultivated for later analysis. For cultivation, specimens were placed in an incubator at $20^{\circ} \mathrm{C}$ and repeatedly subsampled (Table 1). The seawater was changed twice a week to maintain good oxygenation. The foraminifers were first fed after 10 days, and from then on (1) once per week with $1 \mathrm{ml}$ of dried Chlorella algae, and (2) twice per week with two strains of Phaeodactylum $(1 \mathrm{ml}$ of each).

Each analysed individual of A. tepida was carefully selected for its coloration indicating the presence of live cytoplasm or for the presence of a cyst indicating that they were feeding or reproducing and hence alive and healthy. Specimens that contained no measurable proteins were assumed dead and were not included in any of the following calculations relative to the protein content. Specimens were picked from all size classes $(>100 \mu \mathrm{m})$ to ensure that our data represent the in-situ assemblage of $A$. tepida and to enable identification of ontogenetic changes of the size-to-biomass relation. Each foraminifer was transferred into a bath of microfiltered seawater and gently cleaned with a brush to remove all particles stuck to the specimen including organic matter. Subsequently, specimens were washed for one second in deionized water to remove the seawater. Each foraminifer was then stored individually in an Eppendorf cup and frozen at $-80^{\circ} \mathrm{C}$ to prevent disintegration of the proteins. For each of the different preparation methods, foraminifers were unfrozen and divided randomly between (1) the specimens that were crushed and served as control, and (2) the specimens used for testing one of the five preparation methods on the entire foraminifer tests. This insured that the two subsamples were representative of the original sample and that the protein content depended only on the preparation method and not on the order in which the foraminifers were processed.

To establish the relationship between protein content and test size, 104 foraminifer specimens from the November sampling campaign were analysed (Table 1). Each specimen was morphometrically analysed before deep-freezing. The foraminifers were then unfrozen and crushed, and the cytoplasm protein content was analysed.
Table 1. Dates of sampling and sample processing in 2010, cultivation periods (days), and number of specimens of A. tepida picked from each sample at different cultivation times.

\begin{tabular}{rrrr}
\hline $\begin{array}{r}\text { Sampling } \\
\text { Date }\end{array}$ & $\begin{array}{r}\text { Processing } \\
\text { Date }\end{array}$ & $\begin{array}{r}\text { Cultivation } \\
\text { Period }\end{array}$ & $\begin{array}{r}\text { Number of } \\
\text { Specimens }\end{array}$ \\
\hline $13 / 05$ & $14 / 05$ & 1 & 45 \\
$13 / 05$ & $17 / 05$ & 4 & 52 \\
$13 / 05$ & $19 / 05$ & 6 & 49 \\
$13 / 05$ & $25 / 05$ & 12 & 42 \\
$13 / 05$ & $21 / 06$ & 39 & 60 \\
$13 / 05$ & $24 / 06$ & 42 & 31 \\
$20 / 07$ & $21 / 07$ & 1 & 60 \\
$20 / 07$ & $04 / 08$ & 15 & 29 \\
$20 / 07$ & $05 / 08$ & 16 & 30 \\
$23 / 11$ & $24 / 11$ & 1 & 104 \\
$23 / 11$ & $02 / 12$ & 9 & 30 \\
$23 / 11$ & $08 / 12$ & 15 & 29 \\
$23 / 11$ & $15 / 12$ & 22 & 29 \\
\hline
\end{tabular}

\subsection{Analytical protocol}

\subsubsection{Preparation of the "working reagent" (WR)}

The WR was produced by mixing 50 parts of BCA with 1 part of copper solution. The BCA solution was composed of bicinchoninic acid, sodium carbonate, sodium tartrate, and sodium bicarbonate in $0.1 \mathrm{~N}$ sodium hydroxide. The copper solution was composed of $4 \%(w / v)$ copper (II) sulphate pentahydrate (kit number BCA-1, Sigma). Mixing the two reagents produces a solution of light green colour. The WR is stable over $24 \mathrm{~h}$ at ambient temperature, and could thus be prepared long before the addition of the proteins.

\subsubsection{Preparation of the protein standards set (StS)}

A protein StS was prepared using a solution of bovine serum albumin (BSA; Sigma-Aldrich) at a protein concentration of $1.0 \mathrm{mg} \mathrm{ml}^{-1}$. Different concentrations of protein standards were produced by dilution with de-ionized (Milli-Q) water or micro-filtered tap water to a certain volume of proteinBSA solution (Table 2). For each concentration, three replicates were produced by adding $20 \mu$ of the protein solution to 18 Eppendorf cups. $400 \mu$ of WR were added to each cup containing protein solution. Protein standards and WR were mixed for $3 \mathrm{~s}$ using a vortex (Lab Dancer, LaboTech).

The protein standards were incubated to obtain a coloration of the solution resulting from the protein concentration. The chemical reaction and resulting coloration depend on incubation time and temperature, which needed to be adjusted to the application to foraminifer protein contents and to produce a solution of measurable differences in colour intensity. Different incubation times and temperatures were tested on several protein StSs. An optimum colour spectrum was obtained at an incubation time of $24 \mathrm{~h}$ at room 
Table 2. Volumes of BSA and MilliQ- or tap water used to prepare the StS. For analyses of the specimens treated with an osmotic shock and ultrasonication, StSs of 0-20 $\mu$ g protein concentration were used. For $\mathrm{NaOH}$ treatment and for specimens sampled in November, standards of $0-10 \mu \mathrm{g}$ of protein concentration were used.

\begin{tabular}{rrrrrr}
\hline $\begin{array}{r}\text { Final } \\
\text { protein }\end{array}$ & $\begin{array}{r}\text { Milli-Q or } \\
\text { Protein } \\
\text { standard BSA } \\
(\mu \mathrm{l})\end{array}$ & $\begin{array}{r}\text { Total } \\
\text { filtered tap } \\
\text { water }(\mu \mathrm{l})\end{array}$ & $\begin{array}{r}\text { StS from } \\
\text { volume } \\
(\mu \mathrm{l})\end{array}$ & $\begin{array}{r}\text { StS to } 20 \mu \mathrm{g} \\
\text { of proteins }\end{array}$ & $\begin{array}{r}0 \text { to } 10 \mu \mathrm{g} \\
\text { of proteins }\end{array}$ \\
\hline 0 & 0 & 80 & 80 & yes & yes \\
2 & 8 & 72 & 80 & yes & yes \\
4 & 16 & 64 & 80 & no & yes \\
5 & 20 & 60 & 80 & yes & no \\
6 & 24 & 56 & 80 & no & yes \\
8 & 32 & 48 & 80 & yes & yes \\
10 & 40 & 40 & 80 & yes & yes \\
15 & 60 & 20 & 80 & yes & no \\
20 & 80 & 0 & 80 & yes & no \\
\hline
\end{tabular}

Table 3. Equations of the regressions of the StS of each experiment (Exp.), number of standards (\# std.) analysed, standard deviation $\left(R^{2}\right)$, probability $(p)$, and standard error of the residuals (SE res.) associated with the regression.

\begin{tabular}{lrrrrr}
\hline Exp. & \# std. & Equation of the Regression & $R^{2}$ & $p$ & SE res. \\
\hline$(1)$ & 63 & $y=-5.103 \times 10^{-5} x^{2}+1.001 \times 10^{-2} x+3.706 \times 10^{-3}$ & 0.9965 & $<0.001$ & 0.003559 \\
$(2)$ and (3) & 63 & $y=-5.124 \times 10^{-5} x^{2}+1.081 \times 10^{-2} x+2.664 \times 10^{-3}$ & 0.9935 & $<0.001$ & 0.005281 \\
$(4)$ & 63 & $y=-1.012 \times 10^{-4} x^{2}+1.260 \times 10^{-2} x+3.517 \times 10^{-3}$ & 0.9901 & $<0.001$ & 0.00704 \\
$(5)$ & 54 & $y=1.508 \times 10^{-4} x^{2}+3.495 \times 10^{-3} x-4.127 \times 10^{-4}$ & 0.9638 & $<0.001$ & 0.003351 \\
Nov. 1 & 54 & $y=9.276 \times 10^{-5} x^{2}+9.663 \times 10^{-3} x-3.456 \times 10^{-3}$ & 0.9944 & $<0.001$ & 0.002753 \\
Nov. 9, 15, 22 & 54 & $y=9.970 \times 10^{-5} x^{2}+9.059 \times 10^{-3} x-4.560 \times 10^{-3}$ & 0.9893 & $<0.001$ & 0.003607 \\
\hline
\end{tabular}

temperature $\left(20 \pm 2{ }^{\circ} \mathrm{C}\right)$. After incubation, each cup was centrifuged for $3 \mathrm{~s}$ at $5000 \mathrm{rpm}$, and the absorbance was measured.

The WR turns very dark at high concentrations of proteins, and its absorbance is affected both by colour and brightness. Polynomial regressions have been used to account for these two factors. Table 3 shows the regression results for the $\mathrm{StSs}$ absorbance data $\left(R^{2}>0.95\right.$; Table 3$)$.

It is important to note that the WR needs to be added to the protein StS and FSS at exactly the same time to make sure that the incubation time and temperature are identical.

\subsubsection{Five different preparation methods for the measurement of the foraminifer cytoplasm protein content}

Five different preparation methods, an osmotic shock with Milli-Q water or micro-filtered tap water, ultrasonication for 2 or $5 \mathrm{~s}$, and $\mathrm{NaOH}$ treatment were applied to the foraminifers in different experiments (Table 4). All the specimens were frozen at $-80^{\circ} \mathrm{C}$ before protein measurement. In each of the different methods, crushed foraminifers served as control group, assuming that the proteins contained in the cytoplasm were quantitatively released to the chemical reagent.
For each of the foraminifer preparation methods tested, the same amount of crushed foraminifers was produced from the same sampling period and cultivation time. For measurement of the protein biomass of crushed specimens, Eppendorf cups with single foraminifers were unfrozen. $20 \mu \mathrm{l}$ of either deionized water or micro-filtered tap water (depending on what was used for the StS and the FSS) and $400 \mu$ lof WR were added to each Eppendorf cup. Foraminifers were then individually crushed with a clean needle to ensure that all the proteins would be released into the solution.

\section{Osmotic shock with Milli-Q water}

Out of 187 specimens of A. tepida sampled in May 2011, 93 specimens were exposed to Milli-Q water to break the membrane of the cytoplasm by osmotic shock (Table 4). Eppendorf cups with single foraminifers were unfrozen, and $20 \mu \mathrm{l}$ of Milli-Q water were added to each cup. We then allowed 30 minutes for the osmotic shock to take place. Then, $400 \mu \mathrm{l}$ of WR were added. Each FSS was mixed for $3 \mathrm{~s}$ with a vortex and incubated for $24 \mathrm{~h}$ at room temperature. Before spectrophotometric measurement, each cup was centrifuged for $3 \mathrm{~s}$ at $5000 \mathrm{rpm}$ to remove any particles from the liquid. The remaining 94 specimens were crushed and analysed for 
Table 4. Overview of the five processing methods for protein quantification plus control group of crushed tests. Specimens submitted to ultrasonication for $5 \mathrm{~s}$ were severely damaged, and the original test weight could not be determined. All specimens that were not crushed were weighed and analysed for their morphometry.

\begin{tabular}{|c|c|c|c|c|c|c|c|}
\hline $\begin{array}{l}\text { Sampling } \\
\text { period }+ \\
\text { cultivation } \\
\text { time (days) }\end{array}$ & Treatment & $\begin{array}{l}\text { Number } \\
\text { of } \\
\text { foram. }\end{array}$ & $\begin{array}{l}\text { Foram. } \\
\text { preparation }\end{array}$ & $\begin{array}{l}\text { Protein } \\
\text { content }\end{array}$ & Weight & Size & Comments \\
\hline & Crush & 92 & $\begin{array}{l}\text { Wash, freeze, crush } \\
\text { after adding WR }\end{array}$ & Yes & No & No & - \\
\hline $\begin{array}{l}\text { May } \\
1,4,6,12\end{array}$ & $\begin{array}{l}\text { (1) } \\
\text { Osmotic } \\
\text { shock }\end{array}$ & 96 & $\begin{array}{l}\text { Wash, freeze, add } \\
20 \mu \text { l of Milli-Q water } \\
30 \text { min before } \\
\text { adding WR }\end{array}$ & Yes & Yes & Yes & $\begin{array}{l}\text { Signs of dissolution } \\
\text { and/or first chamber } \\
\text { damaged, probably } \\
\text { due to low pH }=6.21 \\
\text { of Milli-Q water }\end{array}$ \\
\hline \multirow{3}{*}{$\begin{array}{l}\text { May } \\
39,42\end{array}$} & Crush & 30 & $\begin{array}{l}\text { Wash, freeze, crush } \\
\text { after adding WR }\end{array}$ & Yes & No & No & - \\
\hline & $\begin{array}{l}(2) \\
\text { Osmotic } \\
\text { shock }\end{array}$ & 31 & $\begin{array}{l}\text { Wash, freeze, add } \\
20 \mu \mathrm{l} \text { of micro-filtered } \\
\text { tap water } 30 \mathrm{~min} \\
\text { before adding WR }\end{array}$ & Yes & Yes & Yes & - \\
\hline & $\begin{array}{l}(3) \\
\text { Ultra- } \\
\text { sonication } 2 \mathrm{~s}\end{array}$ & 30 & $\begin{array}{l}\text { Wash, freeze, ultrason. } \\
\text { for } 2 \mathrm{~s} \text { after adding } \\
\text { WR }\end{array}$ & Yes & No & Yes & $\begin{array}{l}\text { Time of ultrason. too } \\
\text { short to break cell } \\
\text { membrane }\end{array}$ \\
\hline \multirow[b]{2}{*}{$\begin{array}{l}\text { July } \\
1\end{array}$} & Crush & 30 & $\begin{array}{l}\text { Wash, freeze, crush } \\
\text { after adding WR }\end{array}$ & Yes & Yes & Yes & - \\
\hline & $\begin{array}{l}(4) \\
\text { Ultra- } \\
\text { sonication } 5 \mathrm{~s}\end{array}$ & 30 & $\begin{array}{l}\text { Wash, freeze, ultrason. } \\
\text { for } 5 \mathrm{~s} \text { after adding } \\
\text { WR }\end{array}$ & Yes & No & Yes & $\begin{array}{l}\text { Time of ultrason. too } \\
\text { long, and tests broken }\end{array}$ \\
\hline \multirow[b]{2}{*}{$\begin{array}{l}\text { July } \\
15,16\end{array}$} & Crush & 29 & $\begin{array}{l}\text { Wash, freeze, crush } \\
\text { after adding WR }\end{array}$ & Yes & Yes & Yes & - \\
\hline & $\begin{array}{l}(5) \\
10 \% \\
\mathrm{NaOH}\end{array}$ & 30 & $\begin{array}{l}10 \mu \mathrm{l} \text { of Milli-Q water } \\
\text { plus } 10 \mu \mathrm{l} \text { of } 10 \% \\
\mathrm{NaOH} \text { in the StS } \\
\text { and FSS }\end{array}$ & Yes & Yes & Yes & $\begin{array}{l}\mathrm{NaOH} \text { seemed to have } \\
\text { interfered with WR }\end{array}$ \\
\hline $\begin{array}{l}\text { November } \\
1\end{array}$ & Crush & 104 & $\begin{array}{l}\text { Wash, freeze, crush } \\
\text { after adding WR }\end{array}$ & Yes & No & Yes & - \\
\hline $\begin{array}{l}\text { November } \\
9,15,21\end{array}$ & Crush & 88 & $\begin{array}{l}\text { Wash, freeze, crush } \\
\text { after adding WR }\end{array}$ & Yes & No & Yes & - \\
\hline
\end{tabular}

their protein content (Table 4). The individuals submitted to an osmotic shock were analysed for their protein content, cleaned, dried, photographed and weighed (Table 4).

\section{Osmotic shock with micro-filtered tap water}

This method is similar to the previous one, but micro-filtered tap water was used instead of Milli-Q water. The osmotic shock was applied in the same way, and the FSS preparation was the same. We analysed 46 specimens from the May sample (Table 4). 28 specimens were crushed, and 18 specimens were submitted to an osmotic shock from micro-filtered tap water $(0.2-\mu \mathrm{m}$ polycarbonate membrane filter, Whatman). The tap water had a higher $\mathrm{pH}(\mathrm{pH}=8.18)$ than Milli-Q water $(\mathrm{pH}=6.21)$ and was thus less corrosive to the calcareous foraminifer shells. In this experiment, micro-filtered tap water was also used for the preparation of the StS. The protein content from the two batches of entire and crushed individuals was measured (Table 5). The individuals submitted to an osmotic shock were weighed and analysed for their morphometry. 
Table 5. Comparison of protein concentrations analysed with different preparation methods. Protein concentrations are compared within each experiment, and not between experiments. Specimens with no measurable protein content were interpreted as dead and data were not further used. The mean protein content of all individuals is given along with the standard deviation. The probability $(p)$ is associated with the variance analysis comparing each treatment to the control (crushed individuals). Values marked with an asterisk $\left({ }^{*}\right)$ are significantly different from the control group of crushed individuals.

\begin{tabular}{|c|c|c|c|c|c|}
\hline $\begin{array}{l}\text { Sampling } \\
\text { period and } \\
\text { cultivation } \\
\text { time (days) }\end{array}$ & $\begin{array}{l}\text { Number of } \\
\text { specimens }\end{array}$ & Treatment & $\begin{array}{l}\text { Mean } \\
\text { protein } \\
\text { content }\end{array}$ & $\begin{array}{l}\text { Standard } \\
\text { deviation }\end{array}$ & $\begin{array}{l}p \text { Comp. } \\
\text { control }\end{array}$ \\
\hline \multirow{2}{*}{$\begin{array}{l}\text { May } \\
1,4,6,12\end{array}$} & 90 & Crush & 2.040 & 1.084 & Control \\
\hline & 93 & $\begin{array}{l}\text { (1) Osmotic shock } \\
\text { (Milli-Q water) }\end{array}$ & 1.491 & 1.140 & $<0.001^{*}$ \\
\hline \multirow{3}{*}{$\begin{array}{l}\text { May } \\
39,42\end{array}$} & 28 & Crush & 1.020 & 0.715 & Control \\
\hline & 18 & $\begin{array}{l}\text { (2) Osmotic shock } \\
\text { (micro-filtered tap } \\
\text { water) }\end{array}$ & 0.428 & 0.282 & $<0.01^{*}$ \\
\hline & 28 & $\begin{array}{l}\text { (3) Ultra- } \\
\text { sonication (2s) }\end{array}$ & 0.886 & 0.812 & 0.348 \\
\hline \multirow{2}{*}{$\begin{array}{l}\text { July } \\
1\end{array}$} & 23 & Crush & 0.682 & 0.641 & Control \\
\hline & 21 & $\begin{array}{l}\text { (4) Ultra- } \\
\text { sonication }(5 \mathrm{~s})\end{array}$ & 0.410 & 0.259 & 0.122 \\
\hline July & 29 & Crush & 1.588 & 0.835 & Control \\
\hline 15,16 & 9 & (5) $10 \% \mathrm{NaOH}$ & 2.589 & 2.604 & 0.075 \\
\hline
\end{tabular}

\section{Ultrasonication for $2 \mathrm{~s}$}

Ultrasonication for $2 \mathrm{~s}$ was applied to 31 specimens from the May sample (Table 4). This experiment was conducted in parallel to the previous experiment (2), and the same control group of crushed specimens was used (Table 4). Foraminifers were unfrozen, $20 \mu \mathrm{l}$ of micro-filtered tap water were added to each Eppendorf cup, WR was added, and the FSSs were submitted to ultrasonication for $2 \mathrm{~s}$. They were vortexed several times over a 24-h incubation period at room temperature. The FSSs were then centrifuged. The protein content of ultrasonicated individuals was measured, and the tests were weighed and analysed for their morphometry.

\section{Ultrasonication for $5 \mathrm{~s}$}

Foraminifers were unfrozen and prepared in the same way as for the previous experiment, but were ultrasonicated for $5 \mathrm{~s}$. 60 individuals from July were analysed. Half of the specimens were crushed, and the remaining 30 specimens were ultrasonicated. The protein content of the ultrasonicated foraminifers was measured and compared with the crushed specimens. The uncrushed tests were morphometrically analysed.

\section{5. $\mathrm{NaOH}$ treatment}

A solution of $10 \%$ sodium hydroxide $(\mathrm{NaOH})$ was applied to break the cellular membranes of A. tepida and to release the cytoplasm content to the WR (Piña-Ochoa et al., 2010). Due to a known interaction with the BCA solution, the final concentration of sodium hydroxide had to be maintained below $100 \mathrm{mM}$ (BCA technical bulletin, Sigma-Aldrich). For this purpose, the Eppendorf cups containing foraminifers were unfrozen, and $10 \mu \mathrm{l}$ of $10 \% \mathrm{NaOH}$ and $10 \mu \mathrm{l}$ of Milli-Q water were added. The FSSs were vortexed and $400 \mu \mathrm{l}$ of WR were added. After a 24-h incubation period at room temperature, the FSSs were centrifuged and the absorbance of the 562-nm wavelength was measured. Note that for this treatment, $10 \mu \mathrm{l}$ of the Milli-Q water of each standard of the protein standard set had to be replaced by the same volume of $10 \% \mathrm{NaOH}$ to take the interaction between the $\mathrm{NaOH}$ and the $\mathrm{BCA}$ solution into account.

The $\mathrm{NaOH}$ method was applied to 59 specimens from the July sampling campaign. About half of the specimens were crushed (29), and 30 specimens were analysed with complete tests (Table 4). Both the crushed and complete specimens were treated with a solution of $10 \mu \mathrm{l}$ of Milli-Q water plus $10 \mu \mathrm{l}$ of a $10 \% \mathrm{NaOH}$ solution, and the protein content was analysed. The foraminifers submitted to $10 \% \mathrm{NaOH}$ were weighed and morphometrically analysed. 


\subsection{Effect of cultivation on protein content}

Large A. tepida ( 88 specimens $>250 \mu \mathrm{m}$ ) from the November campaign were picked at different cultivation times (30 specimens after 9 days, 29 sp. after 15 days, and 29 sp. after 21 days; see Table 1) to analyse the effect of cultivation on the protein content. Each specimen was photographed and measured before deep-freezing. The foraminifers were then unfrozen and crushed for the protein measurement, and compared to the specimens sampled at different cultivation intervals (May and July batches; Table 4).

\section{Results}

\subsection{Protein data produced with the different preparation methods}

1. The mean protein contents of crushed specimens $(2.040 \mu \mathrm{g})$ and specimens submitted to an osmotic shock using Milli-Q water $(1.491 \mu \mathrm{g})$ were significantly different $(p<0.001$; Table 5). Some of the foraminifer tests were damaged by the Milli-Q water, i.e. tests were partly dissolved, and the last chamber was broken in several specimens, probably because of test dissolution at the low $\mathrm{pH}$ of the Milli-Q water $(\mathrm{pH}=6.21)$.

2. The mean protein content of the crushed foraminifers was $1.020 \mu \mathrm{g}$, and $0.428 \mu \mathrm{g}$ for foraminifers submitted to an osmotic shock using micro-filtered tap water, being significantly different between the two batches $(p<0.01$; Table 5). In contrast to the treatment with Milli-Q water (see above) the tests of A. tepida were not damaged by the use of micro-filtered tap water.

3. The mean protein content was $0.886 \mu \mathrm{g}$ for individuals ultrasonicated for $2 \mathrm{~s}$, and not significantly different from the crushed foraminifers $(1.020 \mu \mathrm{g}, p=0.348$; Table 5). Some of the ultrasonicated individuals were partly broken, though, which would explain why their protein content was not significantly different from the crushed individuals. In turn, some of the individuals submitted to ultrasonication were still filled with cytoplasm after treatment, indicating that the proteins were partly not measured.

4. Most of the individuals showed damaged tests after $5 \mathrm{~s}$ of ultrasonication. The last chamber was missing in many specimens, and in some individuals several chambers were broken (see Fig. 1). The morphometry of the broken individuals could hence not be compared with that of the other experiments and was not used in the following discussion about protein-to-size relation. The mean protein content was $0.682 \mu \mathrm{g}$ for the crushed foraminifers and $0.410 \mu \mathrm{g}$ for the ultrasonicated foraminifers, being not significantly different $(p=0.122$; Table 5).

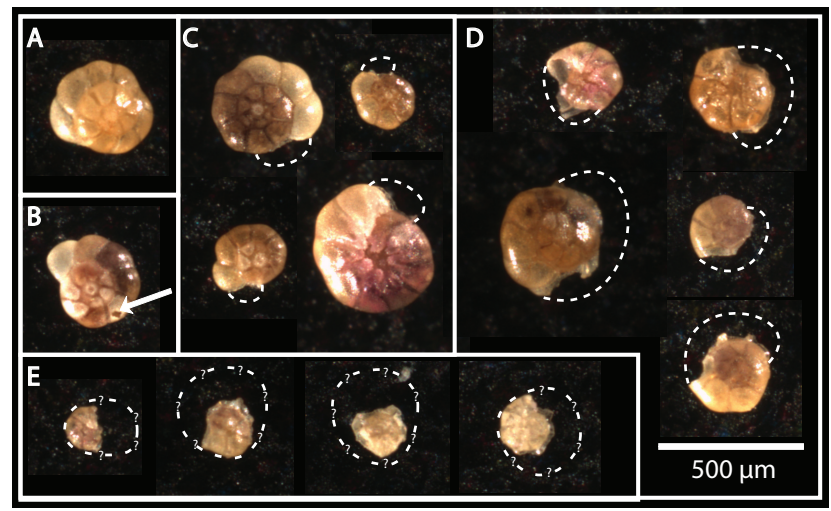

Fig. 1. Examples of the different levels of damaged A. tepida submitted to ultrasonication for $5 \mathrm{~s}$. Dashed lines give a reconstruction of the damaged parts of the test. (A) Test of A. tepida with an intact test. (B) Test with a hole in the middle of a chamber. (C) Individuals with the last chamber missing. (D) Individuals with several external chambers missing. (E) Individuals with only the inner chambers intact, making it difficult to reconstruct the original shape and size of the test.

5. The mean protein content of the crushed foraminifers was $1.588 \mu \mathrm{g}$, and $2.589 \mu \mathrm{g}$ for the specimens submitted to $\mathrm{NaOH}$ treatment, being significantly different $(p=0.075$; Table 5). The strong interaction between the WR and $10 \% \mathrm{NaOH}$ seems to increase the variability of the intensity of the colour between the different replicates of the StS, and this might be also true for the FSS. When measuring small protein quantities, a strong variability between the replicates indicated that the quality of the data must be considered less good than in the other methods.

\subsection{Effect of cultivation on protein content}

The mean protein contents of $A$. tepida from each sampling campaign in May, July, and November, and for each cultivation interval between 1 and 42 days are shown in Fig. 2a. Only the protein contents of the crushed specimens are compared, to avoid any effect due to differences between analytical methods. The test size distribution for each sampling and cultivation time for all uncrushed specimens submitted to an osmotic shock (both Milli-Q and micro-filtered tap water), ultrasonication for $2 \mathrm{~s}$, and $10 \% \mathrm{NaOH}$ treatment is shown in Fig. 2b. Given that these two groups of crushed and uncrushed foraminifers belong to the same population, we assume that the size distribution was similar for the crushed and uncrushed foraminifers and that differences in protein content can be related to test size.

Protein content and minimum test diameter for each sampling batch vary over the duration of cultivation (Table 1, Fig. 2, and Table 6). The minimum test diameter is used as a measure of size to allow comparability of our data 
Table 6. Development of protein content and size (minimum diameter) of A. tepida from the three sampling campaigns in May, July, and November 2010, and for all cultivation intervals between 1 and 42 days. Specimens with no measurable proteins were interpreted as dead and were not used for the variance analysis. The probability $(p)$ associated with the variance analysis between the subsample of the cultivation time and the previous subsample. Values marked with an asterisk $\left(^{*}\right)$ are significantly different from the previous subsample.

\begin{tabular}{|c|c|c|c|c|c|c|c|c|c|}
\hline \multirow[b]{2}{*}{$\begin{array}{l}\text { Sampling } \\
\text { Date }\end{array}$} & \multirow[b]{2}{*}{$\begin{array}{r}\text { Time of } \\
\text { Culturing }\end{array}$} & \multicolumn{4}{|c|}{ Protein content $(\mu \mathrm{g})$} & \multicolumn{4}{|c|}{ Size $(\mu \mathrm{m})$} \\
\hline & & $\begin{array}{l}\text { Number of } \\
\text { Specimens }\end{array}$ & Mean & $\begin{array}{l}\text { Standard } \\
\text { Deviation }\end{array}$ & $\begin{array}{l}p \text { Comp. } \\
\text { Previous }\end{array}$ & $\begin{array}{l}\text { Number of } \\
\text { Specimens }\end{array}$ & Mean & $\begin{array}{l}\text { Standard } \\
\text { Deviation }\end{array}$ & $\begin{array}{l}p \text { Comp. } \\
\text { Previous }\end{array}$ \\
\hline \multirow{6}{*}{$13 / 05$} & 1 & 29 & 1.909 & 1.129 & - & 14 & 352.34 & 73.14 & - \\
\hline & 4 & 51 & 2.130 & 1.110 & 0.397 & 0 & - & - & - \\
\hline & 6 & 0 & - & - & - & 48 & 348.44 & 70.44 & 0.857 \\
\hline & 12 & 10 & 1.960 & 0.843 & 0.647 & 31 & 361.25 & 49.95 & 0.382 \\
\hline & 39 & 18 & 0.898 & 0.562 & $<0.001^{*}$ & 39 & 370.55 & 42.52 & 0.403 \\
\hline & 42 & 10 & 1.238 & 0.924 & 0.235 & 20 & 340.11 & 42.71 & $0.012^{*}$ \\
\hline \multirow{3}{*}{$20 / 07$} & 1 & 23 & 0.682 & 0.641 & - & 0 & - & - & - \\
\hline & 15 & 14 & 1.361 & 0.689 & $<0.005^{*}$ & 15 & 372.62 & 62.13 & - \\
\hline & 16 & 15 & 1.800 & 0.925 & 0.161 & 15 & 354.74 & 61.91 & 0.437 \\
\hline \multirow{4}{*}{$23 / 11$} & 1 & 102 & 0.723 & 0.513 & - & 104 & 243.5 & 52.89 & - \\
\hline & 9 & 25 & 0.414 & 0.282 & $0.004 *$ & 30 & 283.31 & 36.17 & $<0.001^{*}$ \\
\hline & 15 & 25 & 0.622 & 0.415 & $0.043^{*}$ & 29 & 289.42 & 30.32 & 0.486 \\
\hline & 22 & 24 & 0.477 & 0.416 & 0.228 & 29 & 293.91 & 26.42 & 0.550 \\
\hline
\end{tabular}

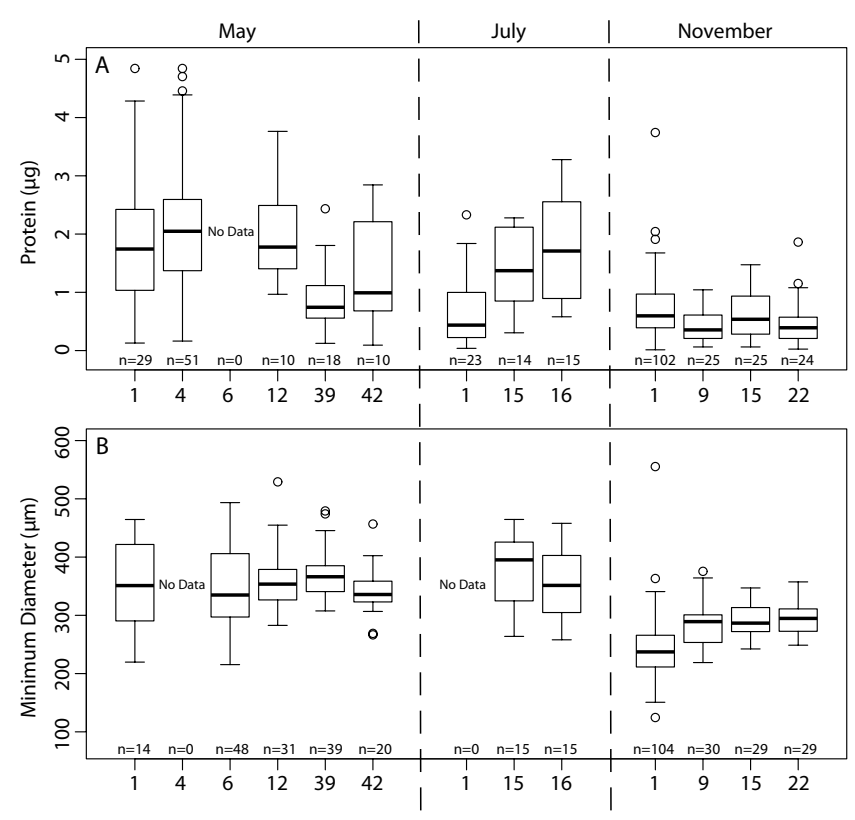

Fig. 2. (A) Protein content of crushed A. tepida of the three sampling campaigns in May, July, and November 2010, and for all cultivation intervals of 1 to 42 days $(n=373)$. (B) Development of the minimum diameter of non-crushed $A$. tepida of the different sampling campaigns and cultivation intervals. Individuals represented here are all the non-crushed individuals, i.e. the specimens treated with an osmotic shock, ultrasonication for $2 \mathrm{~s}$, and $10 \% \mathrm{NaOH}$ $(n=374)$. to size fractions of sieved foraminifers. Freshly sampled foraminifers (incubation interval = 1 day) from the three different sampling campaigns were significantly different regarding their mean protein content $(p<0.001)$ and test size $(p<0.001)$, and can hence not be directly compared. In the May samples, the only significant decrease in protein content occurred between 12 and 39 days of incubation (Table 6), and the only significant change in size occurred between 39 and 42 days of incubation (Fig. 2). In the July samples, a significant increase in protein content occurred between 1 and 15 days of incubation. In the November samples, a significant decrease in protein content occurred between 1 and 9 days, and 9 and 15 days of incubation, and a significant increase in size occurred between 1 and 9 days of incubation (Fig. 2 and Table 6).

\subsection{Relation between foraminifer protein content, test size, and test weight}

The protein content of the 104 specimens of $A$. tepida sampled in November 2010 (Tables 1 and 4) was correlated to a minimum test diameter with an $R^{2}=0.462(p<0.00001$; residual standard error $=0.626$; Fig. 3 ). The correlation between protein content and minimum test diameter is described by the equation

$y=5.537 \times 10^{-8} x^{2.941}$,

with $\mathrm{y}$ being the protein content $(\mu \mathrm{g})$ per individual and $\mathrm{x}$ being the diameter $(\mu \mathrm{m})$ of the test.

The size of $A$. tepida ranged from 124 to $555 \mu \mathrm{m}$. The mean test weight of $A$. tepida with a minimum diameter of 


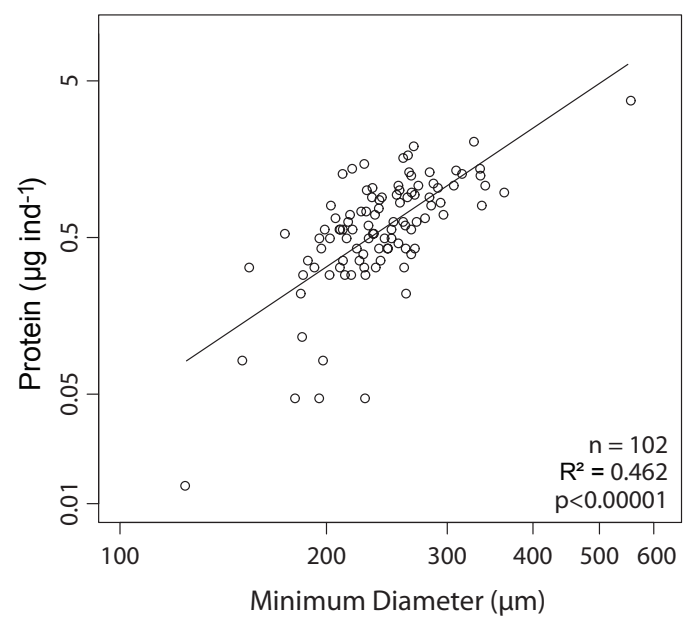

Fig. 3. Correlation between protein content and minimum test diameter of A. tepida. Residual standard error $=0.626$. Without the single large specimen $>500 \mathrm{~m}$, the correlation is still significant $\left(R^{2}=0.439, p<0.00001\right.$, residual standard error $=0.626$, exponential fit).

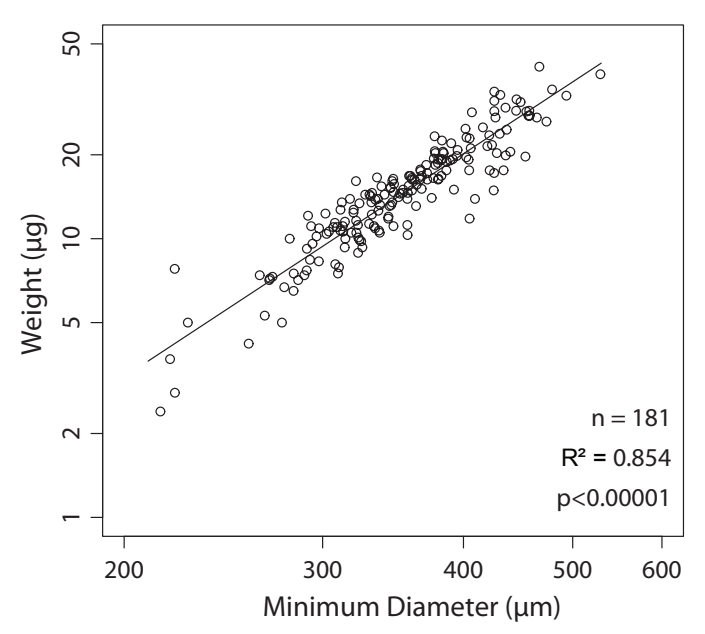

Fig. 4. Correlation between minimum test diameter of A. tepida and shell weight. All individuals measured and weighed during this study are shown (residual standard error $=0.181$, exponential fit).

124- $250 \mu \mathrm{m}$ was $4.3 \mu \mathrm{g}, 9.13 \mu \mathrm{g}$ in the $>250-315 \mu \mathrm{m}$ size class, $18.1 \mu \mathrm{g}$ in the $>315-500 \mu \mathrm{m}$ size class, and $38.9 \mu \mathrm{g}$ in the $>500 \mu \mathrm{m}$ size class (one specimen only).

The ultrasonicated individuals were not weighed, because a majority of the tests were partly broken. Similarly, foraminifers that were crushed were not weighed. In the other experiments, 181 tests were both measured for their size and weighed. The relation between minimum test diameter and weight is shown in Fig. 4. Both parameters, minimum test diameter and test weight, are correlated with an $R^{2}=0.855$ $(p<0.00001$; residual standard error $=0.181)$. The correlation between test weight and minimum diameter is described

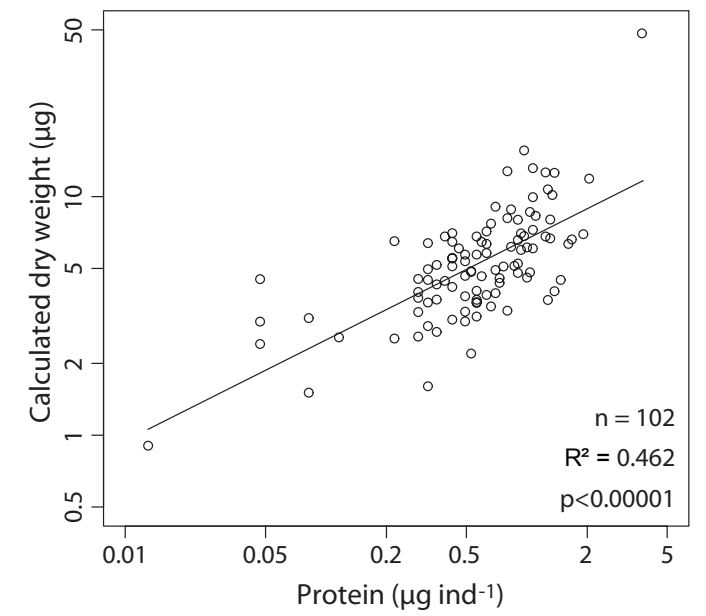

Fig. 5. Calculated dry weight (Eq. 3) calculated for individuals of A. tepida sampled in November 2010 (residual standard error $=0.387$, exponential fit).

by the equation

$y=2.424 \times 10^{-6} x^{2.661}$,

with y being the dry weight $(\mu \mathrm{g})$ of the empty test and $\mathrm{x}$ being the diameter $(\mu \mathrm{m})$ of the test.

Equation (2) was used to calculate the weight of the individuals analysed using size and protein content of A. tep$i d a$. Test weight and protein content are correlated (Fig. 5) with an $R^{2}=0.462(p<0.00001$; residual standard error $=0.387$ ), described by the equation

$y=6.638 x^{0.423}$,

with $y$ being the calculated dry weight ( $\mu \mathrm{g})$ of the test and $x$ being the protein content $(\mu \mathrm{g})$ per individual.

\section{Discussion}

\subsection{Foraminifer preparation}

Different methods - (1) osmotic shock, (2) ultrasonication, and (3) $\mathrm{NaOH}$ treatment - were applied for protein quantification of hard-shelled foraminifers while maintaining the foraminifer tests for further analyses of, for example, test morphometry and allometric development, and chemical composition. Since all specimens were frozen at $-80^{\circ} \mathrm{C}$ before protein measurement, formation of ice crystals could have damaged the cellular membrane and contributed to cytoplasm exposure to the analytical reagents.

1. An osmotic shock with Milli-Q water or micro-filtered tap water did not heavily damage the tests of A. tep$i d a$ but did also not produce complete release of the proteins to the analytical chemicals (WR). The low efficiency of the method might be caused by restricted 
penetration of the Milli-Q water and WR through the small apertures of $A$. tepida. The method might work better on foraminifer species with larger apertures, for example, most planktic foraminifer species. However, we recommend the use of micro-filtered tap water instead of Milli-Q water to avoid any dissolution of the test.

2. Ultrasonication appeared to break the tests. Time and intensity of ultrasonication could not be sufficiently adjusted to the shell thickness of each specimen analysed, though. The use of the method should be restricted to well-defined samples, and would need to be calibrated to each foraminifer species and robustness of its test to ultrasonication. Some species with very thin tests would probably be destroyed even at lower intensities and shorter time intervals of ultrasonication, for example, planktic foraminifers.

3. $10 \% \mathrm{NaOH}$ appears to interact with the working reagent (WR). This experiment shows a regression curve that is less good than in the other experiments (see Table 3). The replicates differ in absorbance values, and the standards for 4 and $6 \mu \mathrm{g}$ of protein overlap for a small range of absorbance values between 0.017 and 0.019 . This could be due to the interference of $10 \% \mathrm{NaOH}$ with the WR. The different replicates bear a larger variability and lower accuracy than the other StS.

\subsection{Protein content, morphometric parameters, and seasonal variations}

Quantification of individual foraminifer cytoplasm protein content is presented for the first time after Altenbach (1985), and relations between protein content, test morphometry, and test weight are established (Figs. 3, 4 and 5). Based on the specimens analysed here, the average protein content of A. tepida from the mudflats of the Baie de l'Aiguillon ranges at $\sim 1.1 \mu \mathrm{g}$. The mean protein content obtained for A. tepida in this study is consistent with that obtained with the same BCA method for Haynesina germanica and Ammonia beccarii $(0.6$ to $1.4 \mu \mathrm{g})$ from the Hamble estuary at Warsash, Hampshire, UK (Mojtahid et al., 2011).

Significant variations in test size between the sampling batches analysed here are related to variations in protein content. In May, the average protein content and test size were slightly higher than in November (Fig. 2 and Table 6). Since A. tepida is directly exposed to a wide range of environmental changes in the temperate intertidal oceans, such as changes in water temperature, salinity, and abundance of prey, which affect its growth (Bradshaw, 1957, 1961, 1968), changes in test size and volume of cytoplasm are interpreted as seasonal signals. Variation in protein content observed for similar test sizes of A. tepida from similar sampling batches could be explained by the fact that the last chamber was filled with cytoplasm in some individuals and empty in others, and the relation of test size to cytoplasm volume would diverge.

\subsection{Effect of cultivation on protein content}

Considering the different sampling times (i.e. seasons) and possible differences in the metabolic state and timing within the reproduction cycle of A. tepida (Bradshaw, 1957, 1961), we can not unequivocally conclude on a systematic increase or decrease in protein content with increasing incubation time (Table 6, Fig. 2). Further analyses would be needed to unravel the waxing and waning of cytoplasm biomass of A. tepida in laboratory cultures with controlled environmental parameters to assess the effect of different parameters on the test growth and changes in cytoplasm volume and protein concentration of A. tepida. In addition, feeding experiments would need to be carried out with different types and quantities of food.

\section{Summary and conclusion}

Quantification of the protein biomass of individual Ammonia tepida (benthic foraminifera) using bicinchoninic acid and nano-spectrophotometry has been tested and improved. Different methods, i.e. osmotic shock and ultrasonication, are now ready to be applied to protein quantification of benthic and planktic foraminifers. Successful quantification of protein content crucially depends on the complete exposure of cytoplasm to the analytical chemicals, while preserving the foraminifer test for later biogeochemical and morphometric analyses. We suggest exposing foraminifer species with large apertures and foramens (easy penetration of chemicals into the test and complete cytoplasm exposure; i.e. most globigerinids) to an osmotic shock sufficient for quantitative protein analysis. Species with small apertures and robust shells should be processed using ultrasonication for cytoplasm exposure. Specimens with fragile shells should be ultrasonicated with care. $\mathrm{NaOH}$ treatment is not recommended, because it reacts with the analytical chemicals when using the bicinchoninic acid method.

A systematic increase of protein biomass with test size and shell weight of the benthic foraminifer Ammonia tepida is shown. Additional data of different species from a wide variety of ecological conditions would be needed, though, to assess the biogeochemical role of foraminifers in benthic and planktic ecosystems at a regional scale. 
Acknowledgements. We are grateful to Mariéva Denoyelle and Christine Barras for their help with sampling and culturing the A. tepida, and to Dewi Langlet and Meryem Mojtahid for helpful discussions on analytical aspects of our work. We thank Takashi Toyofuku, an anonymous reviewer, and the editor Hiroshi Kitazato for their support in improving the manuscript. This project was financially supported by the Regional Council of the Pays de La Loire, France, to AM.

\section{Edited by: H. Kitazato}

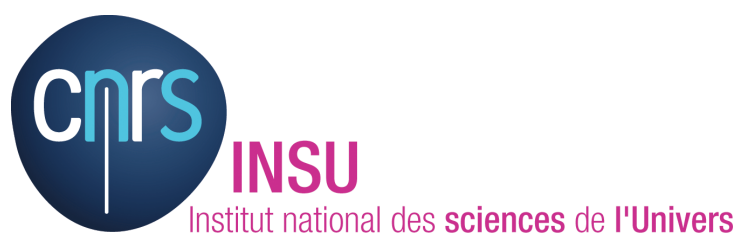

The publication of this article is financed by CNRS-INSU.

\section{References}

Altenbach, A. V.: Die Biomasse der benthischen Foraminiferen, Ph.D. Thesis, Kiel University, 167 pp., 1985.

Altenbach, A. V.: The measurement of organic carbon in foraminifera, J. Foramin. Res., 17, 106-109, doi:10.2113/gsjfr.17.2.106, 1987.

Altenbach, A. V., Unsöld, G., and Walger, E.: The hydrodynamic environment of Saccorhiza ramosa (Brady), Meyniana, 40, 119$132,1988$.

Altenbach, A. V., Pflaumann, U., Schiebel, R., Thies, A., Timm, S., and Trauth, M.: Scaling percentages and distributional patterns of benthic foraminifera with flux rates of organic carbon, J. Foramin. Res., 29, 173-185, 1999.

Altenbach, A. V., Lutze, G. F., Schiebel, R., and Schönfeld, J.: Impact of interrelated and interdependent ecological controls on benthic foraminifera: an example from the Gulf of Guinea, Palaeogeogr. Palaeocl., 197, 213-238, doi:10.1016/S00310182(03)00463-2, 2003.

Bollmann, J., Quinn, P., Vela, M., Brabec, B., Brechner, S., Cortés, M., Hilbrecht, H., Schmidt, D., Schiebel, R., and Thierstein, H.: Automated particle analysis: calcareous microfossils, in Image Analysis, Sediments and Paleoenvironments, 229-252, Dordrecht, The Netherlands, Kluwer Academic Publishers, 2004.

Bradshaw, J. S.: Laboratory Studies on the Rate of Growth of the Foraminifer, Streblus beccarii (Linné) var. tepida (Cushman), J. Paleontol., 31, 1138-1147, 1957.

Bradshaw, J. S.: Laboratory experiments on the ecology of foraminifera, Contributions from the Cushman Foundation for Foraminiferal research, 12, 87-106, 1961.

Bradshaw, J. S.: Environmental parameters and marsh foraminifera, Limnol. Oceanogr., 13, 26-38, 1968.

Clayton, C. R. I., Abbireddy, C. O. R., and Schiebel, R.: A method of estimating the form of coarse particulates, Geotechnique, 59, 493-501, 2009.
Fischer, G. and Wefer, G.: Use of proxies in paleoceanography: examples from the South Atlantic, Springer Verlag, Berlin, 1999.

Goldstein, S. T. and Moodley, L.: Gametogenesis and the life cycle of the foraminifer Ammonia beccarii (Linné) forma tepida (Cushman), J. Foramin. Res., 23, 213-220, 1993.

Gooday, A., Todo, Y., Uematsu, K., and Kitazato, H.: New organicwalled Foraminifera (Protista) from the ocean's deepest point, the Challenger Deep (western Pacific Ocean), Zool. J. Linn. Soc.Lond., 153, 399-423, 2008.

Jorissen, F. J., de Stigter, H. C., and Widmark, J. G. V.: A conceptual model explaining benthic foraminiferal microhabitats, Mar. Micropaleontol., 26, 3-15, 1995.

Lutze, G. F. and Coulbourn, W. T.: Recent benthic foraminifera from the continental margin of northwest Africa: Community structure and distribution, Mar. Micropaleontol., 8, 361-401, doi:10.1016/0377-8398(84)90002-1, 1984.

Lutze, G. and Altenbach, A.: Rupertina stabilis (Wallich), a highly adapted, suspension feeding foraminifer, Meyniana, 40, 55-69, 1988.

Mojtahid, M., Zubkov, M. V., Hartmann, M., and Gooday, A. J.: Grazing of intertidal benthic foraminifera on bacteria: Assessment using pulse-chase radiotracing, J. Exp. Mar. Biol. Ecol., 399, 25-34, 2011.

Moodley, L., Boschker, H., Middelburg, J., Pel, R., Herman, P., de Deckere, E., and Heip, C.: Ecological significance of benthic foraminifera: 13C labelling experiments, Mar. Ecol.-Prog. Ser., 202, 289-295, 2000.

Morvan, J., Debenay, J. P., Jorissen, F., Redois, F., Bénéteau, E., Delplancke, M., and Amato, A. S.: Patchiness and life cycle of intertidal foraminifera: implication for environmental and paleoenvironmental interpretation, Mar. Micropaleontol., 61, 131154, 2006.

Murray, J. W.: The niche of benthic foraminifera, critical thresholds and proxies, Mar. Micropaleontol., 41, 1-7, 2001.

Murray, J. W.: Ecology and applications of benthic foraminifera, Cambridge Univ. Pr., Cambridge, 2006.

Piña-Ochoa, E., Høgslund, S., Geslin, E., Cedhagen, T., Revsbech, N. P., Nielsen, L. P., Schweizer, M., Jorissen, F., Rysgaard, S., and Risgaard-Petersen, N.: Widespread occurrence of nitrate storage and denitrification among Foraminifera and Gromiida, P. Natl. Acad. Sci. USA, 107, 1148-1153, 2010.

Smith, P. K., Krohn, R. I., Hermanson, G. T., Mallia, A. K., Provenzano, M. D., Fujimoto, E. K., Goeke, N. M., Olson, B. J., and Klenk, D. C.: Measurement of protein using bicinchoninic acid, Anal. Biochem., 150, 76-85, 1985.

Suess, E.: Particulate organic carbon flux in the oceans-surface productivity and oxygen utilization, Nature, 288, 260-263, 1980.

Witte, U., Wenzhöfer, F., Sommer, S., Boetius, A., Heinz, P., Aberle, N., Sand, M., Cremer, A., Abraham, W. R., Jorgensen, B., and Pfannkuche, O.: In situ experimental evidence of the fate of a phytodetritus pulse at the abyssal sea floor, Nature, 424, 763766, 2003.

Zubkov, M. V., Fuchs, B. M., Eilers, H., Burkill, P. H., and Amann, R.: Determination of total protein content of bacterial cells by SYPRO staining and flow cytometry, Appl. Environ. Microb., 65, 3251-3257, 1999. 